\title{
IMPLEMENTASI MODEL PROBLEM BASED LEARNING (PBL) UNTUK MENINGKATKAN KEMAMPUAN PEMECAHAN MASALAH MATEMATIS SISWA
}

\author{
Agus Dede Anggiana ${ }^{1}$ \\ ${ }^{1}$ Universitas Pasundan \\ 1 agusdedeanggiana@unpas.ac.id
}

\begin{abstract}
ABSTRAK
Dalam proses pembelajaran kemampuan pemecahan masalah masih kurang baik dalam pembelajaran matematika. Sehingga untuk mengatasi permasalahan tersebut diperlukan model pembelajaran yang lebih memusatkan pada siswa agar lebih aktif dalam berpikir pada kemampuan pemecahan masalah, salah satunya yang diasumsikan dapat meningkatkannya yaitu Model Pembelajaran Problem Based Learning (PBL). Penelitian ini bertujuan untuk mengetahui peningkatan kemampuan pemecahan masalah siswa dengan menggunakan model pembelajaran Problem Based Learning (PBL) dibandingkan dengan siswa yang menggunakan model pembelajaran konvensional. Metode yang digunakan dalam penelitian ini yaitu metode kuasi eksperimen dengan pendekatan dan desain kuantitatif. Instrumen yang digunakan tes kemampuan pemecahan masalah siswa berupa soal uraian yang terdiri dari enam butir soal setiap kemampuan. Populasi dalam penelitian ini yaitu siswa kelas VIII SMPN 1 Cisalak, sedangkan sampel diambil secara purposive dengan hasil pertimbangan kelas terpilih kelas VIII-B sebagai kelas eksperimen dan kelas VIII-C sebagai kelas kontrol. Kelas eksperimen diberi pembelajaran dengan menggunakan model pembelajaran Problem Based Learning (PBL) dan kelas kontrol diberi pembelajaran dengan menggunakan model pembelajaran konvensional. Teknik analisis data menggunakan Uji perbedaan dua rata-rata, Uji Regresi linear, Uji anova satu dan dua jalur. Berdasarkan hasil analisis dan hasil pengolahan data diperoleh simpulan bahwa peningkatan kemampuan pemecahan masalah siswa lebih baik pada kelas Eksperimen yang menggunakan model pembelajaran Problem Based Learning (PBL) dibandingkan dengan kelas kontrol yang menggunakan model pembelajaran konvensional berdasarkan KAM.
\end{abstract}

Kata Kunci : Pembelajaran Berbasis Masalah, Problem Based Learning, Pemecahan masalah.

\begin{abstract}
In the learning process problem solving skills are still not good in mathematics learning. So as to overcome these problems a learning model that is more focused on students is needed to be more active in thinking on problem solving abilities, one of which is assumed to be able to improve it is the Problem Based Learning (PBL) Learning Model. This study aims to determine the increase in students' problem solving abilities using the Problem Based Learning (PBL) learning model compared to students who use conventional learning models. The method used in this research is a quasi-experimental method with quantitative approach and design. The instrument used in the test of students' problem solving skills was in the form of problem statements consisting of six items for each ability. The population in this study were students of class VIII of SMPN 1 Cisalak, while the sample was taken purposively with the results of consideration of the selected class VIII-B as an experimental class and class VIII-C as a control class. The experimental class was given learning by using the Problem Based Learning (PBL) learning model and the control class was given learning by using a conventional learning model. The data analysis technique used two difference test, linear regression test, one and two line ANOVA test. Based on the analysis and data processing results, it can be concluded that the improvement of students' problem solving skills is
\end{abstract}


better in the Experiment class that uses Problem Based Learning (PBL) learning models compared to the control class that uses conventional learning models based on KAM

Keywords: Problem Based Learning, PBL, Problen Solving.

\section{PENDAHULUAN}

Salah satu fungsi mata pelajaran matematika menurut Suherman dkk (2003:56) adalah sebagai alat untuk memecahkan masalah, baik dalam mata pelajaran lain, dalam dunia kerja, maupun dalam kehidupan sehari-hari. Dalam memecahkan masalah, diperlukan pemikiran-pemikiran kreatif. Manusia kreatif memiliki memiliki banyak gagasan dalam memecahkan masalah, diantaranya dengan berbagai pengalaman pribadi yag dilaluinya untuk kemudian diterapkan pada permasalahan yang dihadapi.

Kemampuan pemecahan masalah matematika sangat penting bagi siswa. Pentingnya pemecahan masalah matematika ditegaskan dalam NCTM (2000: 52) yang menyatakan bahwa pemecahan masalah merupakan bagian integral dalam pembelajaran matematika. Namun pada kenyataanya, hasil pengamatan Khasanah, dkk. (2016) menemukan bahwa siswa di Indonesia masih sangat lemah dalam menyelesaikan soal-soal matematika.

Permasalahan matematika bagi siswa, terkadang dianggap tidak memiliki keterkaitan yang erat dengan kehidupan sehari-hari. Ketika diberikan suatu permasalahan, siswa seringkali tidak memahami permasalahan tersebut dan kesulitan menentukan hubungan antar besaran/konsep (Respina dan Masduki, 2017). Padahal menurut de Lange (2004), matematika dapat dilihat sebagai bahasa yang menerangkan pola, pola di alam dan pola yang ditemukan melalui pemikiran manusia.

Pola-pola tersebut bisa berbentuk real (nyata) ataupun berbentuk imajinasi, dapat dilihat ataupun dirasakan, statis ataupun dinamis, kualitatif ataupun kuantitatif, berkaitan dengan kehidupan sehari-hari atau tidak lebih dari sekedar keperluan rekreasi. Hal-hal tersebut dapat muncul dari lingkungan sekitar atau dari hasil kerja pikiran manusia. Oleh karena itu sangat jelas bahwa kebutuhan siswa terhadap matematika lebih kepada kemampuan berpikir.

Untuk mengatasi perubahan pandangan terhadap matematika tersebut, ada beberapa kompetensi atau kemampuan yang menurut de Lange (2004) harus dipelajari dan dikuasai para siswa selama proses pembelajaran matematika di kelas, yaitu:

1. Berpikir dan bernalar secara matematis (mathematical thinking and reasoning). 
2. Berargumentasi secara matematis (mathematical argumentation). Dalam arti memahami pembuktian, mengetahui bagaimana pembuktian, mengikuti dan memulai rangkaian argumentasi, memiliki kemampuan menggunakan heuristis (strategi), dan menyusun argumentasi.

3. Berkomunikasi secara matematis (mathematical communication). Dapat menyatakan pendapat dan ide secara lisan, tulisan, maupun bentuk lain serta mampu memahami pendapat dan ide orang lain.

4. Pemodelan (modeling). Menyusun model matematis dari suatu keadaan atau situasi, menginterpretasi suatu model matematis dalam konteks lain atau pada kenyataan sesungguhnya, bekerja pada model-model, memvalidasi model, serta menilai model matematis yang sudah disusun.

5. Penyusunan dan pemecahan masalah (problem posing and solving). Menyusun, memformulasi, mendefinisikan, dan memecahkan masalah dengan berbagai cara.

6. Representasi (representation). Membuat, mengartikan, mengubah, membedakan, dan menginterpretasi representasi dan bentuk matematika lain, serta memahami hubungan antar bentuk atau representai tersebut.

7. Symbol (symbol). Menggunakan bahasa dan operasi yang menggunakan simbol baik formal maupun teknis.

8. Alat dan teknologi (tool and technology). Menggunakan alat bantu dan alat ukur, termasuk menggunakan dan mengaplikasikan teknologi jika diperlukan.

Kemampuan berpikir diperlukan setiap individu untuk mampu bersaing dan bertahan dalam persaingan global yang semakin ketat memerlukan individu yang memiliki kemampuan berpikir logis, kritis dan kreatif. Individu kreatif menggunakan pengetahuan untuk membuat strategi dan cara serta inovasi-inovasi baru. Individu kreatif akan memandang masalah sebagai tantangan yang harus dihadapi dan harus dicari penyelesaian dari berbagai alternatif yang memungkinkan untuk menjadi solusi.

Sebagai praktisi pendidikan, alternatif solusi yang dapat ditempuh dalam membekali siswa dengan kemampuan pemecahan masalah matematis yang baik, salah satunya adalah dengan membangun proses pembelajaran yang tepat. Namun pada kenyataannya, menurut Mahmudi dan Sumarmo (2010), peran dan tanggung jawab institusi pendidikan pada saat ini belum optimal. Pendapat ini didukung dengan temuan hasil penelitian yang dilakukan oleh McGregor di Amerika, yaitu dua pertiga warga Amerika yang berusia 16 tahun sampai dengan 25 tahun tidak dibekali dengan 
kemampuan-kemampuan yang berguna untuk menghadapi tantangan dalam kehidupan.

Kemampuan-kemampuan tersebut diantaranya adalah kemampuan berpikir kreatif dan melakukan pemecahan masalah (McGregor, 2007). Selain itu menurut Subandar (2008), terdapat fakta yang memaparkan bahwa pembelajaran yang monoton dengan cara tradisional tidak dapat mengembangkan kemampuan berpikir siswa secara optimal, terdapatnya pandangan bahwa proses berpikir yang baik akan mengantarkan seseorang pada pemahaman yang lebih mendalam di berbagai disiplin ilmu, pandangan bahwa kecerdasan dapat dipelajari, sehingga tentu dapat pula diajarkan.

Hal tersebut sesuai dengan hasil study pendahuluan yang dilakukan oleh peneliti di kelas VIII SMPN 1 Cisalak pada tahun 2018. Hasil dari study pendahuluan tersebut menunjukan kemampuan pemecahan masalah matematis siswa tergolong rendah. Dari 20 siswa kelas VIII yang diteliti, terdapat 7 siswa (35\%) yang memiliki kemampuan merancang rencana penyelesaian masalah, sementara itu hanya 5 siswa (25\%) yang melaksanakan rencana tersebut, dan hanya 3 siswa (15\%) yang melaksanakannya dengan sesuai dan memeriksa ulang langkah penyelesaiannya apakah telah sesuai.

Ditinjau dari individu yang terlibat dalam proses pembelajaran, penyebab siswa mengalami kesulitan dalam pemecahan masalah matematika, dapat bersumber dari siswa, teman, maupun guru. Hingga kini masih banyak siswa yang beranggapan bahwa matematika merupakan mata pelajaran yang sulit. Inilah yang menjadi salah satu faktor penghambat terjadinya proses belajar, yaitu; siswa bahkan telah menyerah sebelum memulai.

Menurut Sumarmo (2010), kemampuan berpikir matematis tingkat tinggi, yang salah satunya adalah pemecahan masalah matematis, memerlukan sikap atau disposisi dalam pengembangannya. Sikap kritis, kreatif, cermat, obyektif, terbuka, menghargai keindahan matematika, rasa ingin tahu dan senang belajar matematika adalah sikap yang diperlukan seiring dengan kemampuan berpikir yang berkembang. Pentingnya disposisi matematis juga tercantum dalam kompetensi matematika dalam ranah afektif yang menjadi tujuan pendidikan matematika di sekolah menurut kurikulum 2006 adalah memiliki sikap menghargai kegunaan matematika dalam kehidupan, yaitu memiliki rasa ingin tahu, perhatian, dan minat dalam mempelajari matematika, serta sikap ulet dan percaya diri dalam pemecahan masalah (Depdiknas, 2006).

Kemampuan pemecahan masalah matematika merupakan salah satu bagian yang penting dalam belajar matematika. Kemampuan pemecahan masalah perlu dimiliki siswa 
agar mereka dapat menggunakannya secara luwes baik untuk belajar matematika lebih lanjut, maupun untuk menghadapi masalah-masalah lain. Dalam rangka meningkatkan kemampuan pemecahan masalah matematika, telah banyak upaya yang dilakukan untuk memperbaiki aspek-aspek yang berkaitan dengan kegiatan pembelajaran, antara lain perbaikan terhadap tujuan, kurikulum, pelaksanaan, pembelajaran, evaluasi, juga terhadap kualifikasi guru. Hal tersebut menjadi tugas dan tanggung jawab semua unsur-unsur pendidikan termasuk guru.

Hendaknya guru dapat mengembangkan/menerapkan suatu strategi pembelajaran yang lebih efektif untuk meningkatkan kemampuan pemecahan masalah, mengingat kenyataannya bahwa pemecahan masalah merupakan kegiatan matematika yang paling penting dan sulit dipelajari. Dalam menerapkan suatu strategi pembelajaran sebaiknya siswa dihadapkan pada proses pembelajaran dimana mereka dapat mengkonstruksi pengetahuan secara langsung, artinya siswa dapat merasakan sendiri pengalaman dalam mencapai pemahaman suatu konsep baik melalui benda manipulatif, maupun dengan berinteraksi langsung dengan lingkungan belajarnya.

Menggunakan metode pengajaran yang terlalu kaku juga menjadi kendala dalam pembelajaran matematika, sehingga menimbulkan opini bahwa matematika itu sulit. Kualitas dan keberhasilan pembelajaran sangat dipengaruhi oleh kemampuan dan ketepatan guru dalam memilih dan menggunakan metode pembelajaran, karena metode pembelajaran adalah cara atau alat yang digunakan oleh guru untuk mencapai tujuan pembelajaran menggunakan teknik-teknik tertentu, dengan demikian, kemandirian siswa dan berpikir kreatif dalam belajar dapat terlatih dan proses pembelajaran akan berlangsung secara fleksibel sehingga mendukung pengembangan pengetahuan, sikap, moral dan ketrampilan siswa.

Menyadari pentingnya suatu sistem pembelajaran untuk mengembangkan kemampuan pemecahan masalah, maka diperlukan adanya pembelajaran matematika yang lebih banyak melibatkan aktivitas siswa. Menurut Ruseffendi (2006), kreativitas siswa dapat dikembangkan apabila dilatih melalui eksplorasi, inkuiri, penemuan, dan pemecahan masalah.

Model pembelajaran Problem Based Learning (PBL) yaitu pembelajaran diorientasikan kepada pemecahan berbagai masalah terutama yang terkait dengan aplikasi materi pelajaran di dalam kehidupan nyata. Selama siswa melakukan kegiatan pemecahan masalah, guru berperan sebagai tutor yang akan membantu mereka mendefinisikan apa 
yang mereka tidak tahu dan apa yang mereka perlu ketahui untuk memahami dan atau memecahkan masalah. (Newbledan dalam Gintings, $2010: 210$ ).

Berdasarkan uraian diatas dapat disimpulkan bahwa melalui pembelajaran berbasis masalah (Problem Based learning), proses pembelajaran tidak berhenti hanya karena peserta didik telah menemukan jawaban. Namun juga melatih siswa untuk menemukan solusi alternatif dan melakukan refleksi terhadap hasil pekerjaannya. Hal tersebut dapat mendorong siswa untuk berfikir kritis dan kreatif dalam menyelesaikan permasalahan matematika.

Oleh karena itu, artikel ini bermaksud untuk memaparkan hasil penelitian mengenai peningkatan kemampuan pemecahan masalah matematis siswa melalui model problem based learning.

Masalah dalam matematika diartikan sebagai suatu situasi atau keadaan dimana seseorang tidak dapat menjawab dengan cara atau kebiasaan yang berlaku. Subagiyana (2007) menyatakan bahwa masalah matematis merupakan suatu masalah yang memuat situasi yang mendorong seseorang untuk menyelesaikannya akan tetapi tidak tahu langsung apa yang harus dikerjakan untuk menyelesaikannya.

Sebagian ahli pendidikan matematika menyatakan bahwa masalah merupakan pertanyaan yang harus dijawab atau direspon, namun mereka menyatakan pula bahwa tidak semua pertanyaan otomatis akan menjadi masalah. Suatu pertanyaan dikatakan masalah hanya jika pertanyaan itu menunjukkan adanya suatu tantangan yang tidak dapat dipecahkan oleh suatu prosedur yang rutin yang sudah diketahui siswa.

Dalam hubungannya dengan kemampuan pemecahan masalah matematis siswa, NCTM (1989) menyatakan bahwa pemecahan masalah merupakan salah satu yang menjadi fokus utama dalam pembelajaran matematika, oleh karena itu penerapan pembelajaran berbasis masalah dalam matematika sangat berpotensi untuk mengembangkan kompetensi siswa.

Strategi dalam pemecahan masalah berisi seperangkat langkah-langkah penyelesaian dalam menemukan solusinya. Menurut Brueckner (1961) langkah- langkah pemecahan masalah adalah sebagai berikut; (1) menemukan apa yang menjadi pertanyaan dari permasalahan yang diberikan, (2) menemukan fakta-fakta dari permasalahan tersebut, (3) mencoba berfikir tentang cara untuk menemukan jawaban dari pertanyaan permasalahan, (4) melakukan perhitungan, Pada penelitian ini kemampuan pemecahan yang digunakan adalah langkah pemecahan masalah Polya (1973), yang meliputi: 
a) Memahami masalah

Memahami masalah adalah kegiatan yang sangat penting dalam menyelesaikan suatu masalah. Dalam memahami masalah, indikator yang menyangkut memahami masalah antara lain: (1) Hal-hal apa yang sudah diketahui?; (2) bagaimana kondisi data?; (3) apakah data yang ada sudah cukup?. Pada proses memahami masalah ini siswa diharapkan mampu menuliskan semua data yang diperolehnya

b) Menyusun rencana

Tahap menyusun rencana ini ditentukan dengan kemampuan siswa dalam menghubungkan antara hal yang tidak diketahui dengan hal yang diketahuinya. Berikutnya disusun rencana pemecahan masalahnya dengan memperhatikan: (1) apakah siswa dapat menggunakan algoritma untuk menyelesaikan masalah tersebut?; (2) teori mana yang dapat digunakan untuk menyelesaikan permasalahan tersebut?; (3) apakah semua data sudah dapat digunakan?. Pada proses ini siswa mampu melakukan sistematika langkah-langkah penyelesaian

c) Melaksanakan rencana

Tahap melaksanakan rencana pemecahan masalah adalah menjalankan rencana pemecahan yang telah disusun pada tahap kedua. Pada proses ini siswa mengkaji: (1) apakah rencana yang disusun tersebut telah sesuai?; (2) bagaimana membuktikan bahwa langkah-langkah tersebut telah tepat yaitu memperoleh jawaban yang benar.

d) Memeriksa kembali

Dalam tahap memeriksa kembali jawaban ini siswa dituntut untuk mengontrol hasil pengerjaan dari awal sampai akhir kegiatan pemecahan masalah. Pada proses ini siswa mengkaji: (1) bagaimana cara memeriksa kebenaran hasil yang diperoleh?; (2) dapatkah diperiksa sanggahannya?; (3) dapatkah dicari hasil itu dengan cara lain?; (4) dapatkah hasil dan atau cara itu digunakan untuk soal- soal lainnya?

Menurut Sumarmo (2010) masalah matematik mempunyai dua makna yaitu: 1) Pemecahan masalah sebagai suatu pendekatan pembelajaran, yang digunakan untuk menemukan kembali (reinvention) dan memahami materi, konsep, dan prinsip matematika. Pembelajaran diawali dengan penyajian masalah atau situasi yang kontekstual kemudian melalui induksi siswa menemukan konsep/prinsip matematika; 2) Pemecahan masalah sebagai kegiatan yang meliputi:

a) mengidentifikasi kecukupan data untuk pemecahan masalah; 
b) membuat model matematik dari suatu situasi atau masalah sehari-hari dan menyelesaikannya;

c) memilih dan menerapkan strategi untuk menyelesaikan masalah matematika dan atau di luar matematika;

d) menjelaskan atau menginterpretasikan hasil sesuai permasalah asal, serta memeriksa kebenaran hasil atau jawaban;

e) menerapkan matematika secara bermakna. Secara umum pemecahan masalah bersifat tidak rutin, oleh karena itu kemampuan ini tergolong pada kemampuan berpikir matematik tingkat tinggi.

The National Council of Teachers of Mathemathics (NCTM) menekankan pemecahan masalah sebagai "fokus sentral dalam kurikulum matematika". Tidak saja kemampuan untuk memecahkan masalah menjadi alasan untuk mempelajari matematika, tetapi pemecahan masalahpun memberikan suatu konteks dimana konsep-konsep dan kecakapan-kecakapan dipelajari. Selain itu, pemecahan masalah merupakan wahana utama untuk membangun kecakapan-kecakapan berpikir tingkat tinggi.

NCTM (2000) menyatakan dalam pembelajaran matematika diharapkan siswa mampu: (1) membangun pengetahuan baru melalui pemecahan masalah; (2) memecahkan masalah matematika maupun dalam konteks lain; (3) menerapkan dan digunakan berbagai strategi yang tepat untuk memecahkan masalah; (4) mengamati dan merefleksikan dalam proses pemecahan masalah matematis.

Pembicaraan sebagian kecil dari salah satu kompetensi kurikulum matematika, yaitu kompetensi problem solving diharapkan para siswa mampu membangun pengetahuan baru matematika, memecahkan permasalahan matematika dalam konteks lain, menerapkan dan mengadaptasi berbagai macam strategi untuk memecahkan masalah, serta memonitor dan merefleksi proses penyelesaian masalah matematika (Turmudi, 2008). Indikator pemecahan masalah matematis dalam penelitian ini adalah: (1) menerapkan dan menggunakan berbagai strategi yang tepat untuk memecahkan masalah; (2) memecahkan masalah matematika maupun dalam konteks lain yang berhubungan dengan kehidupan sehari-hari; (3) menjelaskan atau menginterpretasikan hasil sesuai permasalahan asal, serta memeriksa kebenaran hasil atau jawaban.

\section{METODE PENELITIAN}

Metode penelitian yang digunakan menggunakan metode kuasi eksperimen dengan pendekatan. Indrawan, R. dan Yaniawati, P. (2014 : 51) mengemukakan bahwa "metode 
dalam pendekatan kuantitatif yang selanjutnya disebut penelitian kuantitatif adalah bentuk penelitian ilmiah yang mengkaji satu permasalahan dari suatu fenomena serta melihat kemungkinan kaitan atau Pengaruh -Pengaruh antar variabel dalam permasalahan yang ditetapkan.” Penelitian kuantitatif memiliki tujuan yang dikemukakan oleh Indrawan, R. dan Yaniawati, P. (2014 : 51) "Tujuan penelitian kuantitatif adalah mendapatkan penjelasan tentang besarnya kebermaknaan (Significance) dalam model yang dihipotesiskan sebagai jawaban atasa masalah yang dirumuskan". Metode penelitian yang digunakan pada pendekatan kuantitatif ini adalah metode eksperimen dengan desain eksperimen semu (Quasi Experiment). Menurut Frankel dan Norman E.Wallen (Indrawan, R. dan Yaniawati, P. 2014 :58) "Desain eksperimen semu dilakukan tanpa proses teknik sampel peluang”. Subjek penelitian pada desain ini berjalan alami, misalnya penelitian dalam pembelajaran kelompok mengikuti pembagian kelas yang sudah ada.

Populasi dalam penelitian ini adalah seluruh Siswa Kelas VIII SMPN 1 Cisalak dan sampelnya adalah kelas VIII B (kelas eksperimen) dan VIII C (kelas kontrol). Teknik pengumpulan data yaitu Tes kemampuan pemecahan Masalah.

Desain yang digunakan adalah desain eksperimen semu (Quasi-Eksperiment) yaitu dilakukan tanpa proses teknik sampel peluang (Fraenkel \& Wallen dalam Indrawan dan Yaniawati, 2014), kemudian memilih dua kelas yang setara ditinjau dari kemampuan akademiknya. Kelas yang pertama memperoleh model PBL (kelas eksperimen) dan kelas kedua memperoleh pembelajaran konvensional (kelas kontrol).

\section{HASIL DAN PEMBAHASAN}

Dari hasil pengolahan data untuk masing-masing Kelas diperoleh data seperti yang terdapat pada Tabel 1 berikut

Tabel 1. Data Deskriptif Kedua Kelas

\begin{tabular}{lllllllrl}
\hline & Kelas & $\mathbf{N}$ & $\mathbf{N}_{\mathbf{t}}$ & $\mathbf{M a x}$ & $\mathbf{M i n}$ & $\overline{\boldsymbol{x}}$ & $\overline{\boldsymbol{x}}_{\boldsymbol{t}}$ & $\boldsymbol{\sigma}^{\mathbf{2}}$ \\
\hline Eksperimen & Tinggi & 5 & 26 & 0,85 & 0,65 & 0,76 & 0,57 & 0,08 \\
& Sedang & 16 & & 0,80 & 0,25 & 0,52 & & 0,15 \\
& Rendah & 5 & & 0,65 & 0,25 & 0,44 & & 0,18 \\
\hline Kontrol & Tinggi & 5 & 25 & 0,70 & 0,40 & 0,53 & 0,50 & 0,14 \\
& Sedang & 11 & & 0,80 & 0,30 & 0,57 & & 0.13 \\
& Rendah & 9 & & 0,80 & 0,20 & 0,41 & & 0,23 \\
\hline
\end{tabular}

Berdasarkan data-data yang telah diperoleh dari hasil $\mathrm{N}$ gain terlihat bahwa siswa terbagi menjadi 6 kelompok bagian.Selain itu dilihat dari data yang ada bahwa reratanilai $n$ 
gain pada kelas eksperimen lebih besar daripada kelas control. kategorin gain padasemua kelompok baik itu pada kelas ekperimen dan kontrol merupakan kategori Sedang karena 0,$75 ; 0,55 ; 0,42 ; 0,62 ; 0,57 ; 0,41$ lebih dari 0,3 dan kurang dari 0,7 . Apabila dibandingkan berdasarkan kelas ternyata keduanya termasuk kategori $\mathrm{N}$ gain sedang juga Karena lebih dari 0,3 dan kurang dari 0,7 .

\section{Anova dua Jalur}

Berdasarkan hasil perhitungan dengan menggunakan SPSS, pada kedua kelas itu menunjukan bawah nilainya lebih dari 0,05 yiatu 0,177 yang berarti tidak terdapat perbedaan yang sugnifikan antara kelas ekspeerimen dan kelas kontrol. Hasil perhitungan SPSS yang ditampilaan pada tabel KAM itu menunjukkan bahwa nilai nya kurang dari 0,05 yaitu Sig. $0,006<0,05$ maka $\mathrm{H}_{0}$ ditolak yang berarti bahwa terdapat perbedaan yang signifikan antara kemampuan pemecahan masalah berdasarkan KAM (Tinggi, Sedang, Rendah). Berikut ini data yang lebih lengkap disajikan pada tabel 2 sebagai berikut:

Tabel 2. Uji ANOVA dua jalur Kelas Eksperimen dan Kelas Kontrol

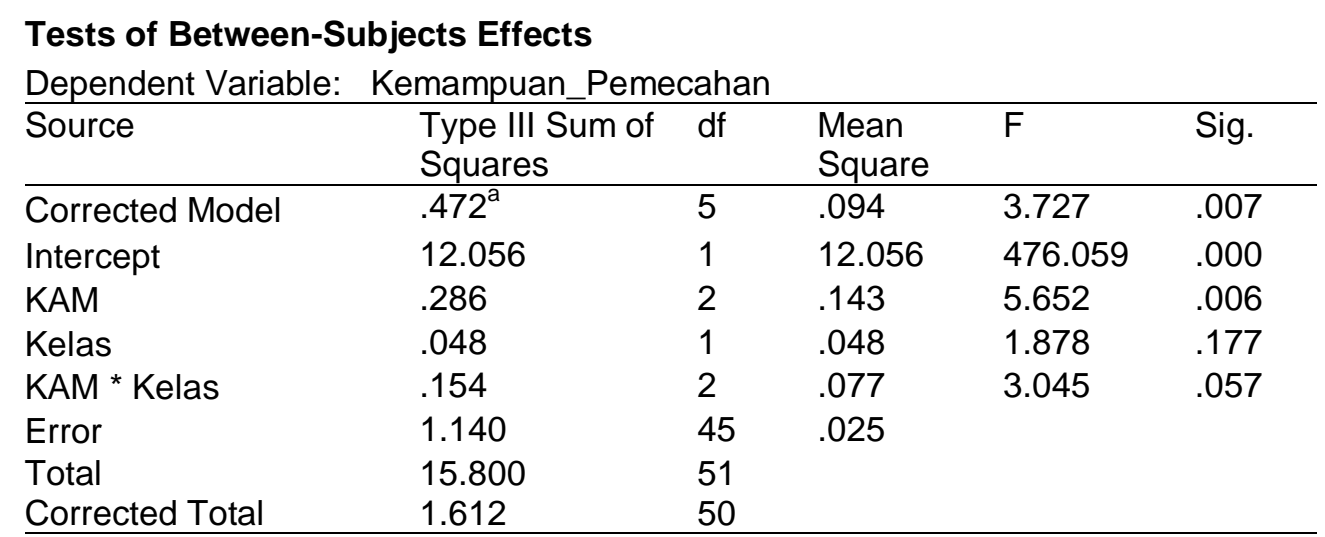

a. R Squared $=.293$ (Adjusted R Squared $=.214)$

Selanjutnya, untuk mengetahui kelompok mana yang berbeda secara signifikan terhadap peningkatan kemampuan pemecahan masalah matematik maka akan dilihat dari uji lanjut ANOVA dua jalur berupa uji Scheffe. Pada tabel berikut disajikan rangkuman data hasil uji Scheffe N-gain kemampuan pemahaman matematis berdasarkan KAM.

Dari Hasil Uji Scheffe berikut yang ditampilkan pada Tabel 2, diketahui bahwa peningkatan kemampuan pemecahan masalah matematik siswa kelompok KAM tinggi tidak berbeda secara signifikan dengan siswa kelompok KAM sedang karena 0,220 > 0,05. Peningkatan kemampuan pemecahan masalah matematik siswa kelompok KAM Tinggi berbeda secara signifikan dengan siswa kelompok KAM rendah karena 0,005 < 0,05. 
Tabel 2. Uji ANOVA dua jalur (uji Scheffe) Kelas Eksperimen dan Kelas Kontrol

\section{Multiple Comparisons}

Dependent Variable: Kemampuan_Pemecahan

Scheffe

\begin{tabular}{|c|c|c|c|c|c|c|}
\hline \multirow[t]{2}{*}{ (I) KAM } & \multirow[t]{2}{*}{ (J) KAM } & \multirow{2}{*}{$\begin{array}{l}\text { Mean } \\
\text { Difference } \\
(I-J)\end{array}$} & \multirow{2}{*}{$\begin{array}{l}\text { Std. } \\
\text { Error }\end{array}$} & \multirow[t]{2}{*}{ Sig. } & \multicolumn{2}{|c|}{ 95\% Confidence Interval } \\
\hline & & & & & $\begin{array}{l}\text { Lower } \\
\text { Bound }\end{array}$ & $\begin{array}{l}\text { Upper } \\
\text { Bound }\end{array}$ \\
\hline \multirow{2}{*}{ Tinggi } & Sedang & .10426 & .058911 & .220 & -.04488 & .25339 \\
\hline & Rendah & $.22714^{*}$ & .065890 & .005 & .06034 & .39394 \\
\hline \multirow{2}{*}{ Sedang } & Tinggi & -.10426 & .058911 & .220 & -.25339 & .04488 \\
\hline & Rendah & .12288 & .052411 & .075 & -.00980 & .25556 \\
\hline \multirow{2}{*}{ Rendah } & Tinggi & $-.22714^{*}$ & .065890 & .005 & -.39394 & -.06034 \\
\hline & Sedang & -.12288 & .052411 & .075 & -.25556 & .00980 \\
\hline
\end{tabular}

Based on observed means.

The error term is Mean Square(Error) $=.025$.

*. The mean difference is significant at the 0.05 level.

Peningkatan kemampuan pemecahan masalah matematik siswa kelompok KAM

Sedang Tidak berbeda secara signifikan dengan siswa kelompok KAM rendah karena $0,075>0,05$.

Jadi, dapat disimpulkan dilihat dari rerata bahwa siswa kelompok KAM tinggi secara signifikan memiki peningkatan kemampuan pemecahan masalah matematik yang lebih baik dibandingkan dengan siswa kelompok sedang dan bawah pada kelas eksperimen maupun kelas kontrol

Hasil Penelitian yang telah dilaksanakan oleh peneliti menghasilkan pembahasan yang akan dijelaskan sesuai dengan hipotesis yang telah diajukan. Peningkatan Kemampuan pemecahan masalah siswa yang menggunakan model pembelajaran Problem Based Learning dan pembelajaran Konvensional

Hasil perhitungan menunjukan bahwa peningkatan kemampuan pemecahan masalah matematis siswa yang pembelajaranya menggunakan model pembelajaran Problem Based Learning dengan lebih baik dibandingkan dengan siswa yang pembelajaranya menggunakan pembelajaran Konvensional berdasarkan KAM (Kemampuan Awal Matematika) kategori Tinggi, Sedang dan Rendah. Hasil yang ditemukan setelah melaksankan penelitian ternyata sesuai dengan pendapat para ahli bahwaAbidin, Yunus (2013:159).

Model Problem Based Learning (PBL) memfasilitasi peserta didik untuk berperan aktif di dalam kelas melalui aktifitas belajar memikirkan masalah yang berhubungan dengan kehidupan sehari-harinya, menemukan prosedur yang diperlukan untuk menemukan informasi yang dibutuhkan, memikirkan situasi kontekstual, memecahkan masalah, dan menyajikan solusi masalah tersebut. 
Pada dasarnya kemampuan pemecahan masalah siswa dengan menggunakan model pembelajaran Problem Based Learning dengan itu dapat membantu siswa dalam memecahkan masalah yang diberikan oleh guru ketika pembelajaran berlangsung, karena ketika siswa telah terbiasa latihan dengan masalah masalah yang diberikan siswa yang dikaitkan dalam kehidupan sehari - hari dan didukung dengan model pembelajaran Problem Based Learning yang dapat membantu serta melatih siswa dalam menyelesaikan saoal kemampuan pemecahan masalah.

Berbeda pada siswa yang menggunakan model konvensional Walaupun memang sering dilatih dengan soal pemecahan masalah tetapi strategi dan modelnya kurang tepat maka tidak akan maksimal. Karena pada pembelajaran konvensional itu berfokus pada guru yang selalu berperan aktif dan siswa cenderung hanya mendengrakan. Berbeda dengan model pembelajaran Problem Based Learning itu berpusat pada siswa sehingga siswa akan menjadi lebih terlatih dan belajar bermakna. Maka hasil skor tes siswa pun akan lebih baik dan cukup memauaskan walupun memangtidak semuanya bisa mencapai skor yang diharapkan, tetapi apabila dibandingkan maka siswa yang menggunakan PBL itu menunujukan angka yang skor rerata yang lebih baik daripda siswa yang menggunakan model konvensional. Pendukung lainnya yaitu PBL memiliki tahapan tahapan agar siswa bisa menjadi lebih terlatih dan terbiasa dengan soal pemecahan masalah, hal ini sesuai dengan Kementrian Pendidikan dan Kebudayaan (2013) tahapan-tahapan dalam PBL dibagi kedalam lima fase:1) Orientasi peserta didik kepada masalah, 2) Mengorganisasikan peserta didik, 3) Membimbing penyelidikan individu dan kelompok, 4) Mengembangkan dan menyajikan hasil karya, 5) Menganalisa dan mengevaluasi proses pemecahan masalah. Maka dari itu siswa menjadi siswa akan lebih aktif pada saat pembelajaran karena berpusat pada siswa.

Apabila dilihat berdasarkan KAM menunjukan bahwa siswa yang termasuk kelompok tinggi itu lebih baik daripada siswa yang termasuk kelompok sedang maupun rendah hal ini terjadi pada siswa yang menggunakan PBL dan konvensional. factor penyebab hal ini adalah kemampuan bawaan yang dimiliki siswa sangat berpengaruh besar karena siswa yang biasa saja terkadang sedikit kesulitan untuk mengejar siswa yang pandai. Selain itu juga terkadang siswa yang pandai juga dalm belajar sangat bsersemangat maka akan sangat berpengaruh dalam hasil skor tes karena belajarnya pun sangat bersunggguh sungguh dan ingin mencapai nilai yang maksimal. Selain itu juga ternyata model pembelajaran pun berpengaruh karena kelompok tinggi pada siswa yang 
menggunakan model PBL lebih baik daripada siswa yang menggunakan model konvenional.

\section{KESIMPULAN}

Berdasarkan hasil penelitian, pengolahan data dan analisis data, serta pengujian hipotesis yang dilakukan mengenai penggunaan model pembelajaran Problem Based Learning (PBL) dan model pembelajaran konvensional, maka penulis menarik kesimpulan Peningkatan kemampuan pemecahan masalah matematis siswa yang menggunakan model PBL lebih baik daripada siswa yang mendapatkan pembelajaran konvensional, ditinjau dari keseluruhan siswa dan kategori kemampuan awal matematika (KAM) siswa (Tinggi, Sedang, dan Rendah).

\section{REKOMENDASI}

Berdasarkan hasil dalam penelitian ini, maka direkomendasikan bahwa guru sebaiknya menggunakan model pembelajaran Problem based Learning (PBL) dalam mengajarkan pembelajaran matematika, siswa hendaknya dapat berperan aktif dalam proses pembelajaran dan hendaknya mencoba membuka diri dan tidak menganggap pusat informasi adalah guru, namun bisa berasal dari teman, buku, televisi, radio maupun internet.Untuk penelitian lebih lanjut, dapat dipergunakan model penelitian yang berbeda. Dengan mengambil sampel dan populasi di tempat lain dan jumlahnya lebih besar. Dengan demikian bisa benar-benar terlihat peningkatan kemampuan pemecahan masalah matematis siswa yang menggunakan model pembelajaran Problem based Learning (PBL).

\section{REFERENSI}

Abidin, Yunus. (2014). Desain Sistem Pembelajaran dalam Konteks Kurikulum 2013. Bandung: PT. Refika Aditama.

Indrawan, R \& Yaniawati, P (2014). Metodologi Penelian, Kuantitatif, Kualitatif, dan Campuran untuk Manajemen, Pembangunan, dan Pendidikan. Bandung. Refika Aditama.

Ruseffendi,E.T.(2006).PengantarkepadaMembantu GuruMengembangkan Kompetensinyadalampembelajaran matematikauntukmeningkatkan CBSA. Bandung: Tarsito.

Rusman. (2013). Model-Model Pembelajaran Mengembangkan Profesionalisme Guru. Bandung. PT Rajagrafindo Persada 
Siswono,TatagY.E.(2004).“BahasadanMatematika:PengalamanObservasidikelasPMRI”.Bu letin PMRI.Edisikeempat.April2004

Sumarmo, U. (2013). "Pembelajaran Matematika". Kumpulan Makalah Berpikir dan Disposisi Matematika serta Pembelajarannya. Bandung: UPI Press.

Sudjana, M. A. (1996). Metoda Statistika. Bandung: Tarsito.

Sugiyono. (2009). Statistika untuk Penelitian. Bandung : Alfabeta.

Sugiyono. 2003. Statistika Untuk Penelitian. Bandung : CV. Alfabeta.

Suherman, E. (2003) Evaluasi Pembelajaran Matematika. Bandung: UPI.

Suherman, E. dkk. (2003). Strategi Pembelajaran Matematika Kontemporer. Bandung: UPI.

Suherman, E. (2001). Evaluasi Proses dan Hasil Belajar Matematika. Jakarta: UT.

Sukaesih, (2008) Pengaruh Pendekatan Creative Problem Solving (CPS)dalam Pembelajaran Matematika terhadap Kemampuan Berpikir Kreatif Siswa. Skripsi pada PPS Unpas. Bandung: Tidak Diterbitkan.

University of Delaware. (2002). PBL Clearinghouse. Retrieved July 15, 2002 from https://www.udel.edu/pblc. (Problems plus teaching notes for the humanities, basic and applied sciences, and the social sciences, protected from student access).

Wardani, Sri. (2002). Pembelajaran Pemecahan Masalah Matematika Melalui Model Kooperatif Tipe Jigsaw. Laporan Penelitian. Tasikmalaya: tidak diterbitkan. 